\section{Ronald J. Burke}

rburke@schulich.yorku.ca

York University

\section{Jacob Wolpin}

Independent Consultant

\section{Ghada El-Kot}

Arab Academy for Science, Technology

and Marine Transport

\title{
Sex Differences in Work \\ Experiences and Work Outcomes among Egyptian Managers and Professionals: An Exploratory Study?
}

\section{Abstract:}

This research examined potential sex differences in work experiences and work outcomes in a sample of Egyptian managers and professionals. Relatively little research has been un-

1. Preparation of this manuscript was supported in part by York University and the Arab Academy for Science, Technology and Maritime Transport. We thank those assisting in the data collection and our respondents. 
dertaken on potential sex differences in human resource management in Egyptian organizations and even less during and following the Arab spring. Data were collected from 121 managerial and professional employees, 77 males and 44 females, using anonymously completed questionnaires. Respondents were relatively young, had university educations, had short job and organizational tenures, and held lower level -management jobs. All measures employed here had been used and validated previously by other researchers. Work experiences included supervisor empowerment behaviors and levels of personal empowerment. Work and well-being outcomes included job satisfaction, organizational commitment, work engagement, exhibiting voice behaviors, workplace learning opportunities, intent to quit and employee health symptoms. Significant sex differences were present on most personal demographic and work situation characteristics: men were at higher organizational levels, earned more money, were older and had longer organizational tenures, among others. There were fewer significant sex differences on work experiences and work outcomes. When differences were observed here, women indicated less positive responses.

\section{Key words:}

sex differences, work, Egyptian organizations, managers

\section{Introduction}

This study examined the relationship of perceived supervisor/leader empowerment practices, employee feelings of psychological empowerment, and important work outcomes among a sample of Egyptian managers and professionals. Empowerment research has typically focused on front-line employees in the service sector, and to the best of our knowledge, no direct research on empowerment has been undertaken in Egypt. We first review empowerment concepts and their potential implications for organizations, consider aspects of the larger Egyptian context, then examine some relevant sex and gender differences research findings from earlier Egyptian and Middle Eastern studies. 


\section{Empowering supervisors, psychological empowerment and performance benefits}

Herrenkohl, Judson and Heffner (1999; p. 375) define empowerment as "a set of dimensions that characterize an environments interaction with persons in it so as to encourage their taking initiative to improve processes and to take action". Empowerment then exists at two levels (Spreitzer, 1997): the organizational context that increases levels of employee empowerment (e.g., structure, policies, approach to decision making, centralized versus decentralized control), and employees feelings of being empowered (feeling encouraged to take risks, supported in showing initiative, having information about organizational priorities).

Measures of empowerment, not surprisingly, have addressed both organizational and individual levels. Matthews, Diaz and Cole (2003) developed a measure of organizational empowerment having three dimensions. Control of workplace decisions - employee input and involvement in decisions and policy making; Dynamic structural framework - organizational guidelines indicating levels of employee input to decision making and control; and Fluidity in information sharing - employees provided with information on company objectives, rewards, and clients/customers. Arnold, Arad, Rhoades and Drasgow (2000) created a measure of leader empowerment behaviors that included five dimensions: Leading by example, Informing employees, Coaching employees, Showing concern for the welfare of employees and interacting with them, and using Participative decision making. At the individual level, Spreitzer (1996, 1995) created a measure of personal or psychological empowerment having four dimensions: Meaning, Competence, Self-determination and Impact. There are relationships between organizational- and individual-level indicators of empowerment, with organizational-level efforts increasing individual level responses. In addition, employee feelings of empowerment would be reflected in more favorable work and well-being outcomes. 


\section{Benefits of organizational and psychological empowerment}

Lawler, Mohrman and Benson (2001) reported that over seventy percent of workplaces have initiated some type of empowerment effort in at least part of their workforce, suggesting the applicability of empowerment concepts for all organizational sectors. Since the empowerment concept seems to be a good fit for organizations, studies on the potential benefits of empowerment have been reported, particularly in the hospitality sector. Kazlauskaite, Buciuniene and Turauskas (2012), using both the Matthews, Diaz and Cole (2003) measure of organizational level empowerment and the Spreitzer (1995) measure of psychological empowerment, examined the relationship of both levels of empowerment with a variety of work outcomes in a sample of 211 front-line service employees at 30 upscale hotels in Lithuania. They reported that organizational empowerment was positively related to psychological empowerment, job satisfaction and affective commitment. Dewettinck and van Amaijde (2010) employed the Arnold et al (2000) measure of supervisor empowering behaviors in a study of 381 front-line employees working in four service organizations, reporting that leadership empowerment behaviors increased levels of both job satisfaction and affective commitment, with psychological empowerment partially mediating these relationships.

\section{The Egyptian context}

Egypt has one of the largest populations in the Middle East and North Africa (MENA) and is the fourth largest economy in this region. The Egyptian economy has not performed well over the past two decades. Egypt faces challenges of being competitive in a global economy, embracing the latest technology, and realizing the importance of human resource management 
in unleashing the talents of employees (Burke \& El-Kot, 2011). The Egyptian educational system does not seem to be doing an adequate job of preparing graduates for the world of work in 2015. Egypt also has high levels of unemployment particularly among educated young people and women. Unemployment among university graduates is estimated to be between 17\% and $27 \%$. Egypt has a relatively high rate of illiteracy. The public sector is the largest employer with about 30\% of Egypt's workforce. The Egyptian economy has historically underperformed, corruption and cronyism being high.

The Arab Spring and massive protests in Tahrir Square in Cairo resulted in the overthrow of long-serving President Hosni Mubarak, an essentially military dictatorship, in January 2011. Mubarak "resigned" on February 4, 2011, after 29 years as President. Free elections, a rarity in Egypt, were held and Mohamed Morsi, leader of the Muslim Brotherhood, an Islamic leaning movement, was elected President in June 2012. Morsi was the first democratically elected President in Egyptian history. Morsi then faced protests in Tahrir Square, some of these involving sexual harassment and the gang rape of female Morsi supporters. During Morsi's one year in office Egypt faced economic difficulties, energy shortages, and political and diplomatic crises, though blamed on Morsi existed before he became President. Morsi was overthrown on July 31, 2013 by a military coup led by Abdel Fattah el-Sisi, who appointed a figurehead President, assuming the Vice Presidency himself. El-Sis then announced an election for President in which he ran against one other person - a sham election. Since then El Sisi's government has suspended the constitution, reduced civil liberties, clamping down on journalists and free speech. Morsi was imprisoned where he remains, hundreds of Morsi supporters shot on August 14, 2013, and thousands of Morsi supporters imprisoned (Eltahawy, 2015).

Economic performance has gotten worse following the Arab Spring as the economy moved from the military dictatorship of Mubarak in 2011, the democratic election of Morsi, and the 2013military coup of EI Sisi. The Egyptian citizenry was seeking a more democratic society which it has not yet achieved. 
Abdou and Zaasou (2011) note the following social and economic challenges now facing Egypt. These include low foreign direct investment, a high budget deficit, a high debt load, reduced tourism, high levels of unemployment, high levels of poverty, a low standard of living, increasing food costs, high inflation rates, and a need to spend money. It does not have to allay further citizen unrest.

\section{Status of gender equality in Egypt}

The 2014 Global Gender Gap Report (World Economic Forum, 2014) ranked 142 countries in four areas: Economic participation and opportunity, Educational attainment, Health and survival, and Political empowerment, as well as developing a composite score. Egypt ranked 131, 109, 57, 134, and 129 on the composite score. In the 9 years that these data were being collected (2006 to 2014), Egypt remained at roughly the same ranking in these areas, showing little sign of improvement.

Egypt is a patriarchal society with women being only a small but growing part of the workforce. (Hofstede. 1980; Metcalfe, 2008; Ramzy, 2002; but Egypt is in transition as more women pursue higher education and more programs, often sponsored by outside organizations, are introduced to support women's advancement into managerial and professional roles.

\section{Managerial and professional women in Egypt}

Several researchers (Jamali, Sidani \& Safieddine, 2005; Tlaiss, 2014, 2013; Kauser \& Tlaiss, 2011; Sidani, 2005; Sidani \& Jamali,2010), based on in-depth interviews with managerial women in various countries (e.g., Lebanaon, United Arab Emirates, Egypt) have attributed the challenges and barriers these women face to the strength of cultural values and 
societal expectations limiting women to traditional roles, a strong sense of patriarchy, and organizational attitudinal and structural factors; the latter including discrimination, inequalities, gender stereotypes and pay inequalities for women and men doing the same job. Egypt ranks near the top in terms of male-female wage gaps.

Sidani and Thornberry (2010) argue that productivity in the vast majority of Arab states is low and dropping. Suggested causes include corruption, mismanagement, red tape and bureaucracy, nepotism, inefficiencies, and a low work ethic. They attribute the latter to the roles of religion, family dynamics and family structures that influence personal and group development, limits in the educational system, power and leadership issues, and limited awareness and use of modern management practices.

Hassanien (2010) suggests the lack of "decent work" for women contributes to the low participation rates of women in the Egyptian workforce, Egypt having the lowest participation rates of women in the world. Women have responsibilities not only to their organization but also unpaid family and domestic work - a double burden. In addition, women must perform in ways at work to conform to cultural values and maintain their reputations. Barsoum, Rashed and Hassanien (2009) highlight the effects of lack of respect and trust from male colleagues, insults to their dignity, sexual harassment, long work hours and unequal pay.

Kattara (2005), in a study of female managers in five star Egyptian hotels, identified five factors keeping them from advancement: gender discrimination, being excluded from important networks, gender stereotyping, cultural barriers, and work-family conflict. Hotels preferred recruiting and hiring males rather than females, females needed to work much harder than males to prove themselves, belief that once married females would become less productive, and promotion might include moving to another city or country and that would not be appropriate for married females.

Burke and El-Kot (2011) examined sex differences and similarities in a sample of 242 Egyptian managers and professionals, 146 males and 96 
females. Consistent with previous findings, there were considerable sex differences in personal demographics and work situation factors. Thus, females were younger, had less job and organizational tenures, were at lower organizational levels and were less likely to be married. Males and females, however, were similar on their needs for achievement, job satisfaction, work engagement and levels of job stress. Males and females differed in career satisfaction with males being higher, intent to quit with females being higher, and perfectionism, with females being higher.

Elsaid and Elsaid (2012), using samples of Egyptian and American university students, examined their stereotypes of characteristics of men, women, and successful middle managers. In the Egyptian sample, males rated men and middle managers positively and women and middle managers negatively. Females rated males and middle managers even more strongly positively and females and middle managers even more negatively. In the US sample, both males and female students had positive ratings for men and middle managers and for females and middle managers. They attributed their findings to the Egyptian cultural belief that women do not have characteristics of successful middle managers but men do. In both countries, men had less favorable attitudes towards women ad managers.

Mostafa (2003), again using a sample of Egyptian students as well as older adults, reported that males held less favorable attitudes than did females, and contrary to expectations, students attitudes were similar to those held by older adults. Mostafa notes that with increasing modernity, these attitudes would likely become more favorable, a belief not borne out by the Elsaid and Elsaid (2012) study.

El-Hamidi and Said (2014) compared the extent of gender occupational segregating and wage gaps between 2000 and 2004 in Egypt and found increasing occupational segregation of women into a few jobs which increased the wage gap.

Hendy (2015) examined the low participation rate of women in the Egyptian labor market at three points in time:1998, 2006 and 2012. Though wom- 
en in Egypt are more educated than men, their participation rates remain low. In addition, the Arab spring revolution in 2011 had a negative effect on women's labor force participation. Reductions in the public sector, discrimination in the private sector, family demands, and women's preferences all were found to play a role in women's low participation rates.

Amin and Darrag (2011) write that no research on sexual harassment in the workplace in Egypt has been carried out. A primary reason for this is a political need to keep sexual harassment secret. Yet sexual harassment in Egypt has taken on epidemic proportions. Women have been sexually assaulted and gang raped in Tahrir Square in Cairo during protests against former President Mubarak in January 2011 and in more recent protests against former President Mohamed Morsi.

Managerial and professional women in Egypt seem to be facing barriers that in some cases are similar to those experienced by managerial and professional women worldwide but others unique to Egypt as well.

\section{The present study}

In this study, we consider potential sex differences in employee perceptions of supervisor/leader empowerment behaviors, levels of felt psychological empowerment, and important work outcomes (job satisfaction, affective organizational commitment, work engagement, engaging in voice behavior, intent to quit, health symptoms) among Egyptian managers and professionals.

Three general hypotheses based on previous sex difference findings among managers and professionals in the Middle East were developed (see Burke, 2009, for a review of sex differences studies in several Middle East countries).

1) There would be considerable significant sex differences on personal and work situation characteristics (e.g., age, marital status, parental sta- 
tus, hours worked, income, job and organizational tenures, and organizational level).

2) There would be fewer significant sex differences on work experiences and work outcomes (e.g., perceptions of leader supervisory empowerment behaviors, job satisfaction, intent to quit).

3) When significant sex differences were present, women would report less favorable responses than men would.

\section{Method \\ Procedure}

All data were collected using anonymously completed questionnaires in English. A team of MBA students approached employees in a range of organizations in Alexandria and Cairo soliciting their participation. One hundred and twenty one surveys were returned, either immediately or within a short period of time. The response rate was estimated to be approximately seventy-five percent. The sample is best described as a convenience sample.

\section{Measures}

\section{Personal and work situation demographics}

Personal and work setting characteristics were assessed by a number of single items. The former included: gender, age, current work status, current marital and parental status, income, and level of education. The latter included hours worked per week, organizational level, job tenure, organizational tenure, Organizational size, employment sector, and whether respondent had supervisory duties. These items served as control variables in some of our analyses. 


\section{Supervisory empowerment behaviors}

Arnold, Arad, Rhoades and Drasgow (2000) developed and validated a measure of empowering leader behaviors. They ended up with five factors: Coaching, Informing, Leading by example, Participative Decision Making, and Showing concern/Interacting with their team. In the present research, each of these five dimensions was measured by five items. Respondents indicated how frequently their supervisor exhibited each behavior on a five point Likert Scale (1=Never, 3=Sometimes, 5=Always).

Leading by example $(\alpha=.90)$ An item was "Leads by example."

Participative decision making ( $\alpha=.93$ ) One item was "Encourages work group members to express their ideas/suggestions".

Coaching $(\alpha=.93)$ An item was "Suggests ways to improve my work group's performance."

Informing ( $\alpha=$.92) One item was "Explains how my work group fits into the company."

Showing concern/Interacting with the team $(\alpha=91$.) An item was "Shows concern for work group members well-being."

Scores on these five dimensions of leader empowerment were significantly and positively correlated (mean inter-correlation being 75, $p<.001$ ). Thus the five dimensions were combined into a total leader empowerment measure $(\alpha=.97)$.

\section{Work outcomes}

Seven work outcomes were included.

\section{Psychological empowerment}

Psychological or personal feelings empowerment was measured by a twelve item scale developed and validated by Spreitzer (1996, 1995). 
This measure tapped four dimensions, each addressed by three items. Respondents indicated their agreement with each item on a seven-point Likert scale (1=Very strongly disagree; 4=Neutral, 7=Very strongly agree).

Meaning ( $\alpha=$.92.) "The work I do is meaningful to me."

Competence $(\alpha=.78)$ "I am confident about my ability to do my job."

Self-determination ( $\alpha=.76$ ) "I have significant autonomy in determining how I do my job."

Impact ( $\alpha=85$ ) "My impact on what happens in my department is large".

Scores on these four dimensions were significantly and positively correlated (mean intercorrelation being .40, p<.001). Thus scores on the four dimensions were combined into an overall psychological empowerment measure $(\alpha=.87)$.

Job satisfaction was assessed by a seven item scale $(\alpha=.84)$ developed and validated by Taylor and Bowers (1972). Respondents indicated their agreement with each item on a five-point Likert scale (1-Very dissatisfied, 3=Neither satisfied nor dissatisfied; 5=Very satisfied. One item was "all in all, how satisfied are you with the persons in your work group?"

Organizational affective commitment was measured by a six item scale $(\alpha=.92)$ developed and validated by Meyer and Allen (1997). Respondents indicated their agreement with each item on a five-point Likert Scale (1=Strongly disagree, 3=Neither agree nor disagree; 5= Strongly agree). One item was "I am proud to tell others I work at my hotel". Work engagement

Three aspects of work engagement were assessed using measures created by Schaufeli, Salanova, Gonzalez-Roma and Bakker (2002). Respondents indicated their agreement with each item on a five point Likert scale (1=strongly disagree, 3=neither agree nor disagree, 5= strongly agree).

Dedication was measured by five items ( $\alpha=89$ ). One item was "I am proud of the work I do."

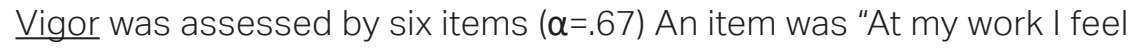
bursting with energy." 
Absorption was measured by six items $(\alpha=.76)$. One item was "I am immersed in my work."

Scores on these three measures were positively and significantly inter-correlated (mean inter-correlation being .64, $p<.001$ ) thus they were combined to form a composite work engagement measure $(\alpha=.88)$.

\section{Learning opportunities}

Workplace learning potential was assessed using a twelve item scale developed by Nikolova, Van Ruysseveldt, DeWitte and Syroit (2014). Four learning potential opportunities were assessed, each by three items. Respondents rated the applicability of each item to their current work situation on a five point Likert scale ( $1=$ Not applicable at all, $5=$ completely applicable). These four dimensions and a sample item follow.

Reflection $(\alpha=.68)$ "In my work I am given the opportunity to contemplate about different work methods".

Experimentation ( $\alpha=.52$ ) "In my job I can try different work methods even if that does not deliver any useful result."

Supervisor ( $\alpha=.78$ ) "My supervisor helps me see my mistakes as a learning experience."

Coworkers ( $\alpha=.76$ ) "My colleagues tell me if I make mistakes in my work."

All of the inter-correlations among the four dimensions were positive, with four being statistically significant. The four dimensions were then combined into a composite measure $(\alpha=.76)$, the average inter-correlation being .28 $(p<01)$.

\section{Employee Voice}

Employee voice behaviors were measured by a six item scale ( $\alpha=.92)$ developed by Van Dyne and LePine (1998). Respondents reported how often they engaged in voice behaviors in their workplaces by indicating the frequency of each item on a five point Likert scale ( $1=$ Never, $3=$ sometime, and 
5=Very frequently). One item was "I speak up in my workplace with ideas for new projects or changes in the way we do things."

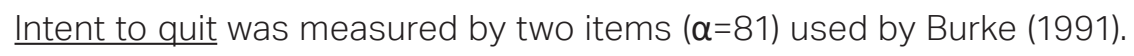
Respondents indicated "yes or no" for both items. One item was "Are you currently looking for a different job in a different organization?"

\section{Psychological well-being}

Psychological well-being was assessed by 19 items ( $\alpha=.90)$ developed by Quinn and Shepard (1974). Respondents indicated how often they experienced each physical symptom or condition (e. g., headaches) in the past year on a four poi8nt frequency scale a(1=never, $4=$ often).

\section{Results}

Respondents

Table 1 presents the personal demographic and work characteristics of our sample (n=121). Most were male (64\%), worked full time (95\%), were 30 years of age or younger (68\%), were married (53\%), without children (55\%), had high school educations (50\%), worked in their present organizations and positions for five years or less (59\% and 84\%, respectively), held lower level management positions (30\%), had supervisory responsibilities (76\%), worked between 41 and 50 hours per week (45\%), a majority earned more than 80,000 Egyptian pound salaries (32\%), slightly more worked in the service sector than in manufacturing (51\%), worked in organizations of varying sizes up to several thousand with a slight majority working in firms of 50 or fewer employees (30\%) and worked in a variety of departments (e.g., production, marketing, finance, accounting, human resources). 
Table 1. Demographic characteristics of sample

\begin{tabular}{|c|c|c|c|c|c|}
\hline Gender & $\underline{N}$ & $\%$ & Age & $\mathrm{N}$ & $\%$ \\
\hline Male & $\overline{77}$ & $\overline{63.6}$ & $\overline{30}$ or younger & 57 & $4 \overline{9} .1$ \\
\hline \multirow[t]{2}{*}{ Female } & 44 & 36.4 & $31-40$ & 45 & 38.8 \\
\hline & & & $41-50$ & 9 & 7.8 \\
\hline Work status & & & 51 or older & 5 & 4.3 \\
\hline Full time & 114 & 95.0 & & & \\
\hline \multirow[t]{2}{*}{ Part-time } & 6 & 45.0 & Marital status & & \\
\hline & & & Single & 64 & 52.9 \\
\hline Parental status & & & Married & 57 & 47.1 \\
\hline$\overline{\text { Children }}$ & 54 & 44.6 & & & \\
\hline \multirow[t]{2}{*}{ Childless } & 67 & 55.4 & Education & & \\
\hline & & & Bachelors & 95 & 78.5 \\
\hline Income & & & Masters & 21 & 17.4 \\
\hline$\overline{25,000}$ or less & 27 & 23.1 & Doctorate & 5 & 4.1 \\
\hline $25,001-50,000$ & 32 & 27.3 & & & \\
\hline $50,001-75,000$ & 20 & 17.1 & $\underline{\text { Organizational level }}$ & & \\
\hline \multirow[t]{2}{*}{75,001 or more } & 38 & 32.5 & $\overline{\text { Non-management }}$ & 30 & 24.8 \\
\hline & & & Lower management & 36 & 29.8 \\
\hline Sector & & & Middle management & 30 & 24.8 \\
\hline$\overline{\text { Manufacturing }}$ & 59 & 49.2 & Senior management & 25 & 20.7 \\
\hline \multirow[t]{2}{*}{ Service } & 61 & 50.8 & & & \\
\hline & & & $\underline{\text { Supervisory duties }}$ & & \\
\hline Work hours & & & Yes & 90 & 75.6 \\
\hline 40 or less & 51 & 42.1 & No & 29 & 24.4 \\
\hline $41-50-$ & 54 & 44.7 & & & \\
\hline \multirow[t]{2}{*}{51 or more } & 16 & 13.2 & Job tenure & & \\
\hline & & & $\overline{5 \text { years or less }}$ & 102 & 84.3 \\
\hline \multicolumn{2}{|c|}{ Organizational tenure } & & 6 years of more & 19 & 15.7 \\
\hline 5 years or less & 71 & 58.9 & & & \\
\hline $6-10$ years & 29 & 23.9 & Organization size & & \\
\hline \multirow[t]{4}{*}{11 years or more } & 21 & 17.4 & 50 or less & 36 & 29.8 \\
\hline & & & $51-500$ & 33 & 22.2 \\
\hline & & & $501-4000$ & 31 & 25. \\
\hline & & & 4001 and above & 21 & 17.4 \\
\hline
\end{tabular}

Source: own study.

Analysis plan

Males and females were compared on all variables using One-Way Analysis of Variance (ANOVA).

\section{Personal and work situation characteristics}

Table 2 presents the comparisons of male and female managers and professionals on a number of personal demographic and work situation char- 
acteristics. Significant sex differences were present on seven of the eleven characteristics. Males were older, more likely to be married, more likely to be parents, were at higher organizational levels, more likely to have supervisory responsibilities, had longer organizational tenures, and more likely to be working in the manufacturing than service sectors. Males and females were similar on work status (almost all worked full-time), levels of education, job tenures and worked in organizations of generally similar sizes.

Table 2. Personal and Work Situation Characteristics

\begin{tabular}{|c|c|c|c|c|c|c|c|}
\hline & & Males & & & Female & & \\
\hline Personal characteristics & $\underline{X}$ & $\underline{\text { S.D }}$ & $\underline{N}$ & $\underline{X}$ & $\underline{\text { S.D. }}$. & $\underline{\mathrm{N}}$ & $\underline{\mathrm{P}}$ \\
\hline Age & 1.8 & .86 & 73 & 1.4 & .63 & 43 & .01 \\
\hline Work status & 1.0 & .16 & 77 & 1.1 & .29 & 43 & NS \\
\hline Marital status & 1.7 & .47 & 77 & 1.2 & .44 & 44 & .001 \\
\hline Parental status & 1.4 & .49 & 77 & 1.8 & .39 & 44 & .001 \\
\hline Education & 3.3 & .58 & 77 & 3.2 & .42 & 44 & NS \\
\hline Organizational level & 2.6 & 1.09 & 77 & 2.1 & .90 & 43 & .05 \\
\hline Supervisory duties & 1.2 & .34 & 77 & 1.4 & .30 & 42 & .01 \\
\hline Job tenure & 3.8 & 2.89 & 77 & 3.6 & 5.06 & 43 & NS \\
\hline Organizational tenure & 8.1 & 7.64 & 76 & 4.9 & 4.15 & 43 & 05 \\
\hline Organizational size & 3450.8 & 8456.42 & 77 & 3542.4 & 8606.48 & 42 & NS \\
\hline Sector & 1.4 & .50 & 77 & 1.6 & .49 & 43 & 05 \\
\hline
\end{tabular}

Source: own study.

\section{Work experiences and work outcomes}

Table 3 shows the comparisons of males and females on measures of work experiences and work outcomes. There were three statistically significant sex differences $(\mathrm{P}<.05)$ on these eleven measures. Males worked more hours, earned higher levels of income, and indicated higher levels of affective organizational commitment. Males also tended to be more job satisfied and work engaged $(p<.10)$ than females as well. There were no sex differences on presence of learning opportunities, perceptions of empowering supervisory behaviors, levels of psychological empowerment, engaging in voice behaviors, intentions to quit and levels of physical well-being. 
Table 3. Work Experiences and Work Outcomes

\begin{tabular}{|c|c|c|c|c|c|c|c|}
\hline Work Experiences & & Males & & & emales & & \\
\hline and Outcomes & $\underline{X}$ & S.D. & $\mathrm{N}$ & $\underline{X}$ & S.D. & $\underline{\mathrm{N}}$ & $\underline{\mathrm{P}}$ \\
\hline$\overline{\text { Hours worked }}$ & $4 \overline{8.3}$ & 12.84 & 77 & 39.5 & 9.90 & $\overline{43}$ & .00 \\
\hline Income & 112054.5 & 140303.99 & 77 & 48986.6 & 61966.58 & 41 & .01 \\
\hline Intent to quit & 3.0 & .92 & 77 & 2.8 & .91 & 43 & NS \\
\hline Job satisfaction & 25.3 & 5.28 & 77 & 23.6 & 5.44 & 44 & .10 \\
\hline Work engagement & 66.7 & 8.43 & 76 & 63.0 & 12.51 & 44 & .10 \\
\hline Learning opportunities & 25.8 & 4.43 & 74 & 27.1 & 4.01 & 44 & NS \\
\hline Psychological & & & & & & & \\
\hline Empowerment & 50.6 & 5.44 & 77 & 49.0 & 7.03 & 44 & NS \\
\hline Organizational & & & & & & & \\
\hline Commitment & 23.6 & 4.82 & 77 & 20.2 & 6.08 & 44 & .01 \\
\hline Voice behaviors & 38.3 & 6.22 & 76 & 36.6 & 7.30 & 44 & NS \\
\hline Supervisor empowering & & & & & & & \\
\hline Behaviors & 83.2 & 23.12 & 77 & 85.4 & 20.44 & 44 & תו \\
\hline Physical health & 41.3 & 9.02 & 77 & 42.5 & 11.32 & 44 & NS \\
\hline
\end{tabular}

Source: own study.

\section{Discussion}

This investigation examined sex differences in personal and work situation characteristics as well as a range of work experiences and work outcomes among managers and professionals in two large Egyptian cities. Consistent with previous published findings, females and males differed considerably on personal and work situation factors (see Table 2). Men were older, had longer organizational tenures, were more likely to be married and to be parents, worked more hours, were at higher organizational levels, and earned higher salaries. Women were as educated as men however.

Earlier research has shown that although women are "disadvantaged" compared to men on personal and work situation measures, they tend to be quite similar on work experiences and outcomes (with the exception of sexual harassment). Our data was somewhat supportive of these previous results (see Table 3). That is there were both similarities and differences Unfortunately when significant sex difference were present, women reported less favorable outcomes. 
Similarities in work experiences and work outcomes might be attributed to the fact that both women and men had the attitudes and behaviors to be successful in their jobs. Difference may be attributed to wider cultural views on women's and men's work and roles in Egypt, family and friendship responsibilities, and women's level of ambition and aspirations. We have viewed these similarities and differences as both signs of progress and indications of what needs to be addressed in the future. It seems that some progress has taken place but Egyptian workplaces should not rest on their laurels - women managers and professionals in Egypt still face unique obstacles and constraints.

It should be noted that our sample was relatively young, highly educated, worked full-time in managerial and professional roles in Egypt's two largest cities, earned reasonable incomes, worked relatively long hours, were moderately satisfied with work outcomes and described generally positive work experiences and had, not surprisingly a low intent to quit. In addition, our data were collected in early 2015, one year after El-Sisi assumed the Presidency and some of the turmoil had likely settled down. Our respondents were functioning and surviving in a country environment characterized by economic recession, uncertainty, and still lingering tensions and conflicts.

\section{Practical implications}

Our data, consistent with previous research on women's work and careers in Egypt, indicated that women had less favorable work outcomes (see Table 3). Egyptian organizations need to utilize the talents of all qualified women and men if they are to be successful. Fortunately, considerable knowledge on initiatives to support the careers of qualified women has accumulated (Wittenbnerg-Cox, 2010). Organizational leaders must be sensitized to why utilizing the talents of all talented women in creating a gender balanced workplace is a business imperative. Educational efforts to support such appreciations must be carried out for both men and women in superviso- 
ry and managerial roles. A number of human resource management programs such as leadership development, identifying talented women and men, , succession planning, work-family support initiatives, holding managers responsible for developing talented women, and measuring the results of these initiatives (Bowen \& Lawler, 1995, 1992).

In addition, given the barriers that Egyptian women face, country-wide efforts need to be taken as well. These would include anti-discrimination policies, equal pay for equal work initiatives, and collaboration with international labor organizations and global organizations providing support to women at work efforts. For example, Goldman Sachs created the women Entrepreneurship and Leadership Program, as part of their 10,000 women initiative in which women entrepreneurs got access to business and management education in developing countries including Egypt.

\section{Limitations of the research}

The present research has shortcomings which should be noted to better assess the findings. First, all data were collected using self-report questionnaires with the risk of response set and common method biases. Second, all respondents came from only two Egyptian cities, Cairo and Alexandria, thus the extent to which our findings would generalize to male and female managers and professionals in other regions in Egypt is unknown. Third, it was not possible to determine the representativeness of the present sample of male and female managers and professionals as well.

\section{Future research directions}

Several future research directions seem promising in increasing our understanding of sex differences among Egyptian managers and professionals. First acquiring a larger, more representative sample that includes longer 
tenured men and women would be informative. Second, including indicators of bias, discrimination and sexual harassment would provide a more complete picture of respondent's work experiences. Third, including assessments of respondents views on their careers, career aspirations, career challenges, and efforts to self-manage their careers, would shed light on other relevant aspects of their work and well-being. Fourth, It is important to understand from Egyptian managers and professionals how the events of the past four years have affected their jobs, careers, organizations, families and their psychological well-being. 


\section{References}

Abdou, D. S., \& Zaazou, Z. (2013) Ehe Egyptian revolution and post socio-economic impact. Topics in Middle Eastern and African Economies, 15, 92-115.

Amin ,A. \& Darrag, M.S. (2011) Sexual harassment in the Egyptian workplace: A literature review and research agenda. Review of Management, 1, 25-39.

Arnold, J. A., Arad, S., Rhoades, J. A., \& Drasgow, F. (2000) The empowering leadership questionnaire: The construction and validation of a new scale for measuring leader behavior. Journal of Organizational Behavior, 21, 249-269.

Barsoum, G., Rached, A. \& Hassinien, D. (2009) At work when the4rre is "no respect": Job quality issues for yong women in Egypt. MENA Gender and Work Working Paper, No. 2. Cairo: Population Council.

Bowen, D.E., \& Lawler, E.E. (1995) Empowering service employees. Sloan Management Review.36, 73-84.

Bowen, D. E., \& Lawler, E. E. (1992) The empowerment of service workers: What, why, how and when. Sloan Management Review, 33, 31-40.

Burke, R. J. (2009) Cultural values and women's work and career experiences [In:] R. S. Bhagat \& R. M. steers (eds.) Cambridge handbook of culture, organizations, and work. Cambridge: Cambridge University Press. pp. 442-461.

Burke, R.J. (1991) Early work experiences of female and male managers and professionals: Reasons for optimism? Canadian Journal of Administrative sciences, 8, 224-230.

Burke, R.J., \& El-Kot, G. (2012) Gender similarities in work and well-being outcomes among managers and professionals in Egypt. International Journal of Gender and Entrepreneurship, 3, 56-74.

Burke, R. J., \& El-Kot, G. (2011) Human resource management research in Egypt. Review of Management, 1, 4-9.

Dewettnick, I. \& van Ameijde, M. (2011) Linking leadership empowerment behavior to employee attitudes and behavioral intentions. Personnel Review, 40, 284-305.

Elsaid, A. M., \& Elsaid, E. (2012) Sex stereotypes of managerial positions. Gender in Management, 27, 81-99.

Eltahawy, M. (2015) Egypt's human rights abuses. National Post, November 25, A13. 
El-Hamidi, F., \& Said, M. (2014) Gender-based wage and occupational inequality in the new millenium, in Egypt. Journal of Developing Areas, 48, 21-41.

Hassanien, D. (2010) Gendering decent work: Obstacles to performativity in the Egyptian workplace. Surfacing, 3, 1-15.

Hendy, R. (2015) Women's participation in the Egyptian labor marked: 1998-2012. Working Paper NO. 907. Giza: Economic Research Forum

Herrenkohl, R. C., Judson, G. T., \& Heffner, J. A. (1999) Defining and measuring employee empowerment. Journal of Applied Behavioral Science, 35, 373-389.

Hofstede, G. (1980) Culture's consequences: International differences in work-related values. Beverly Hills I, CA: Sage.

Jamali, D., Sidani, YI, \& Safieddine, A. (2005) Constraints facing working women in Lebanon: An insider view. Women in Management Review, 20, 581-594.

Kattara, H. (2005) Career challenges for female managers in Egyptian hotels. International Journal of Contemporary Hospitality Management, 17, 238-251.

Kauser, S., \& tlaiss, H. (2011) The Arab women manager: Participation, barriers, and future prospects. Journal of International Business and Economy, 12, 35-56.

Kazlauskaite, R., Buciuniene, I., \& Tarauskas, L. (2012) Organizatioanl and psychooogical empowerment in the HRM-performance linkage. Employee Relations, 34, 138158.

Lawler, E. E., Mohrman, S. A., \& Benson, G. (2001) Organizing for higher performance: Employee involvement, TQM, reengineering, and knowledge management in the fortune 1000. San Francisco: Jossey-Bass

Mathews, R. A., Diaz, W. M., \& Cole, S. G. (2003) The organizational empowerment scale. Personnel Review, 32, 297-318.

Metcalfe, B. D. (2008) Women in management and globalization in the Middle East. Journal of Business Ethics, 83, 85-1000,

Meyer, J. \& Allen, N. (1997) Commitment in the workplace: Theory, research, and applications. Thousand Oaks, CA>: Sage Publications.

Mostafa, M. M. (2003) Attitudes towards women who work in Egypt. Women in Management Review, 1`8, 252-266.

Nikolova, I., Van Ruysseveldt, J., DeWitte, H., \& Syroit, J. (2014) Woprk=based learning: Development and validation of a scale measuring the learning potential of the workplace (LPW). Journal of Vocational Behavior, 84, 1-10. 
Quinn, R.P., \& Shepard, L.J. (1974) The 1972-73 Quality of Employment Survey. Institute for Social Research, University of Michigan. Ann Arbor, Michigan.

Ramzy, N. (2002) Arab women and labor: A study of three Arab societies. Journal of the Social Sciences, 30, 579-607.

Schaufeli, W. B., Salanova, AM., Gonzalez-Roma, V., \& Bakker, A. B. (2002) The measurement of engagement and burnout: $A$ two sample confirmatory factor analysis approach. Journal of Happiness Studies, 3, 71-92.

Sidani, Y. (2005) Women, work and Islam in 'arab countries. Women in Management Review, 20, 498-512.

Sidani, Y. M., \& Jamali, D. (2010) The Egyptian worker: Work beliefs and attitudes. Journal of Business Ethics, 92, 433-450.

Sidani, Y.M., \& Thornberry, J. (2010) The current Arab work ethic: Antecedents, implications, and potential remedies. Journal of Business Ethics, 91, 35-49.

Spreitzer, G.M. (1997) Toward a common ground in defining empowerment. Research in Organizational Change and Development, 10, 31-62.

Spreitzer, G.M. (1996) Social structural characteristics of psychological empowerment. Academy of Management Journal, 39, 483-504.

Spreitzer, G.M. (1995) Psychological empowerment in the workplace: Dimensions, measurement, and validation. Academy of Management Journal, 38, 1442-1465.

Taylor, J. C., \& Bowers, D. (1972) Survey of organizations: A machine-scored standardized questionnaire instrument Ann Arbor, Ml.: Institute for social Research.

Tlaiss, H. A. (2014) Between the traditional and the contemporary: Careers of women managers from a developing Middle Eastern country perspective. International Journal of Human Resource Management, 25, 2858-2880.

Tlaiss, H. A. (2013) Women managers in the United Arab Emirates: Successful careers or what? Equality, Diversity and Inclusion: An International Journal, 32, 756-776.

Van Dyne, L., \& LePine, J. A. (1998) Helping and voice extra-role behaviors: Evidence of construct and predictive validity. Academy of Management Journal, 41, 108-119.

Wittenberg-Cox, A. (2010) How women mean business. New York: John Wiley.

World Economic Forum (2014) The global Gender Gap Report 2014. Geneva: World Economic Forum. 